\title{
Efficiency of a constructed wetland for retention of sediment associated phosphorus
}

\author{
Karin Johannesson, Jonas Andersson and Karin Sundblad-Tonderski
}

\section{Linköping University Post Print}

N.B.: When citing this work, cite the original article.

The original publication is available at www.springerlink.com:

Karin Johannesson, Jonas Andersson and Karin Sundblad-Tonderski, Efficiency of a constructed wetland for retention of sediment associated phosphorus, 2011, Hydrobiologia, (674), 1, 179-190.

http://dx.doi.org/10.1007/s10750-011-0728-y

Copyright: Springer Science Business Media

http://www.springerlink.com/

Postprint available at: Linköping University Electronic Press

http://urn.kb.se/resolve?urn=urn:nbn:se:liu:diva-67880 
Efficiency of a constructed wetland for retention of sediment associated phosphorus

Karin M. Johannesson ${ }^{1 *}$, Jonas L. Andersson ${ }^{2} \&$ Karin S. Tonderski ${ }^{1}$

${ }^{1)}$ IFM Biology, section Ecology, Linköping University, SE-581 83 Linköping, Sweden

${ }^{2)}$ WRS Uppsala AB, SE-753 22 Uppsala, Sweden

* Corresponding author (kajoh@ifm.liu.se)

Keywords: Constructed wetland, long-term retention, diffuse pollution, particulate phosphorus, sediment accretion, sediment phosphorus fractions.

This paper has not been submitted elsewhere in identical or similar form, nor will it be during the first three months after its submission to Hydrobiologia.

27 Text pages

4 Figures

4 Tables 


\begin{abstract}
A constructed wetland ( 2.1 ha; $2 \%$ of catchment area) in southeast Sweden, in a catchment with $35 \%$ arable land on clay soils, was investigated with respect to phosphorus $(\mathrm{P})$ retention, focusing on particulate $\mathrm{P}(\mathrm{PP})$ and sediment accretion. The aims were to i) estimate $\mathrm{P}$ retention and identify the dominating retention processes; ii) investigate how well estimates of $\mathrm{P}$ retention based on inflow-outflow measurements compared with the amount of $\mathrm{P}$ accumulated in the sediment.
\end{abstract}

In- and outflow of $\mathrm{P}$ was measured during four years with continuous flow measurements and flow proportional weekly composite samples. $\mathrm{P}$ in the accumulated sediment was estimated based on core samples and analyzed using sequential fractionation. Total P load during four years was $65 \mathrm{~kg} / \mathrm{ha}$ and intensive sampling events detected $69 \%$ as PP. Based on inflow-outflow estimates the mean $\mathrm{P}$ retention was $2.8 \mathrm{~kg} / \mathrm{ha} / \mathrm{yr}$, or $17 \%$, but the amount of $\mathrm{P}$ accumulated in the inlet zone equated $78 \%$ of the TP load. This discrepancy showed the need to add studies of sediment accumulation to inflow-outflow estimates for an improved understanding of the P retention.

The dominating $\mathrm{P}$ forms in the sediment were organic $\mathrm{P}(38 \%)$ and $\mathrm{P}$ associated with iron or aluminum (39\%), i.e. potentially mobile forms. In areas colonized by Typha latifolia, the amount of $\mathrm{P}$ in the upper sediment layer $(390 \mathrm{~kg}$ ) was more than double the total $\mathrm{P}$ load of $136 \mathrm{~kg}$. Cycling and release in those areas is a potential source of $\mathrm{P}$ that deserves further attention. 


\section{Introduction}

As part of the Baltic Sea Action Plan, the construction of wetlands has been suggested as a measure to reduce the transport of phosphorus $(\mathrm{P})$ from agricultural land to aquatic ecosystems (HELCOM, 2007). Many studies have shown that constructed wetlands can function as effective sinks for P from both point and non-point sources (Reddy et al., 1999; Richardson, 1999; Kadlec, 2005), and also in cold climate regions with high loads in wintertime (e.g. Koskiaho et al., 2003; Braskerud et al., 2005). However, results from input/output studies over a couple of years may not reflect the long-term capacity of wetlands to retain phosphorus. Richardson \& Qian (1999) suggested that the $\mathrm{P}$ concentration in the outflow increases exponentially after a $\mathrm{P}$ loading threshold $\left(1 \mathrm{~g} / \mathrm{m}^{2} / \mathrm{yr}\right)$ has been exceeded, though wetlands may serve the function of reducing $\mathrm{P}$ transport to downstream water bodies even at higher loads than this. To be able to manage such wetlands for a sustained P retention, it is important to identify the dominant retention processes, whether it is sediment sorption of dissolved P (Bruland \& Richardson, 2006), sedimentation of particulate P (Braskerud, 2002; Coveney et al., 2002; Koskiaho et al. 2003) or biological P uptake, or a combination of all.

Several studies have shown that in runoff from agricultural fields in clay and silt dominated areas, the P is transported predominately as particulate P (PP) (Uusitalo et al., 2000; Koskiaho et al., 2003; Uusitalo et al., 2003; Ulén, 2004). In a Finnish study, 73-94\% of the P in runoff from an agricultural area was associated with particulate matter (Uusitalo et al., 2003), whereas 69\% was PP in a Swedish study (Ulén, 2004). PP usually consists of soil particles and organic matter that are eroded from arable land during irrigation, precipitation or snowmelt, either as surface runoff or through the drainage system. Clay particles can contain 12 times the amount of $\mathrm{P}$ found associated with sand particles (Pacini \& Gächter, 1999). A substantial part of this PP is 
potentially bioavailable; e.g. $45 \%$ in a study of a Swedish catchment (Persson, 2001). A recent study of sediments in constructed wetlands confirmed this, as the clay content correlated well with the potentially bioavailable P (Maynard et al., 2009). Hence, wetland retention of clay particles is of prime importance for downstream water bodies prone to eutrophication.

Sedimentation velocities can be predicted for different particle sizes using Stoke's law, and in a study of constructed wetlands in Norway, Braskerud (2003) showed that fine clay particles from arable land had sedimentation velocities similar to coarse clay or silt, indicating a high degree of aggregation. As a result, an efficient retention of $\mathrm{P}$ was observed also at high hydraulic loads, and explained by sedimentation of PP (Braskerud, 2002). However, periods of P release have been observed in several constructed wetlands (e.g. Braskerud, 2002; Koskiaho et al., 2003), and Koskiaho et al. (2003) attributed this to the annual development of vegetation with resuspension occurring during seasons with decaying vegetation. Another process that can release $\mathrm{P}$ is resuspension of PP during high-flow periods, making particle size an important determining factor since large or aggregated particles will be less prone to resuspension.

Both geological, topographical and meteorological conditions differ between regions and affect the loss of clay particles and the degree of aggregation of soil from arable lands. In comparison with Norway, Sweden has lower runoff (220 mm/yr compared to $500 \mathrm{~mm} / \mathrm{yr})$ and erosion (220$650 \mathrm{~kg} / \mathrm{ha} / \mathrm{yr}$ (Ulén, 2006) compared to $100-3500 \mathrm{~kg} / \mathrm{ha} / \mathrm{yr}$ (Øygarden et al., 2006)), but a larger proportion of clayey soils and a high content of colloidal particles in the runoff (Ulén, 2004; Ulén et al., 2007). Hence, though P losses are in the same range: $0.03-1.5 \mathrm{~kg} / \mathrm{ha} / \mathrm{yr}$ for Sweden; 0.3$2.6 \mathrm{~kg} / \mathrm{ha} /$ year for Norway (Ulén et al., 2007), the form in which P is transported can be different. This may reduce the effect of wetlands as sinks for P in clay-dominated agricultural areas; hence 
there is a need for more studies on wetland $\mathrm{P}$ retention in catchments with different characteristics.

Input/output studies suffer from the difficulty to get accurate data on mass inflow and outflow of $\mathrm{P}$, as it is difficult to obtain representative samples of the particulate fraction with an automatic water sampler. The concentrations can be both over- and underestimated, as it is difficult to capture the event-based movement of particles even if flow-proportional sampling is employed (Jarvie et al., 2002). Adding measurements of actual sediment accumulation and the sediment content of $\mathrm{P}$ could result in a better understanding of the fate of PP in wetlands. Apart from the studies by Braskerud (Braskerud et al., 2000; Braskerud 2002, 2003), there have been few efforts focusing on measurements of sediment accumulation and retention/release of PP in wetlands constructed to reduce $\mathrm{P}$ transport from non-point sources in temperate regions.

Simple design models for wetland $\mathrm{P}$ removal usually incorporate the inflow $\mathrm{P}$ concentration, hydraulic load and the residence time (c.f. Kadlec, 2005; Tonderski et al., 2005), but a major constrain is that they do not deal with the variable runoff driven pulses of $\mathrm{P}$ loads that occur in agricultural catchments. Kadlec (2005) cites a successful application of a model for storm water wetlands in Florida that employed a variable P storage component, which increased during periods of high $\mathrm{P}$ availability, and decreased during periods of less available $\mathrm{P}$, and where the wetland at all times was assumed to produce residual sediments containing unavailable $\mathrm{P}$. This implies that more information about factors affecting the accumulation, transformation and release of $\mathrm{P}$ in constructed wetlands receiving agricultural runoff could help to improve predictions of the longevity of wetlands as $\mathrm{P}$ sinks. For wetlands receiving most of the $\mathrm{P}$ in a 
particulate form, understanding the flow driven particle transport dynamics may be one of the most important aspects.

The aims of this study were to i) estimate $\mathrm{P}$ retention and identify the dominating retention processes; and ii) investigate how well estimates of $\mathrm{P}$ retention based on inflow-outflow measurements compared with the amount of $\mathrm{P}$ accumulated in the sediment.

\section{Materials and methods}

Site description

The wetland investigated in this study is situated at Södra Stene farm, in Southeast Svealand, Sweden $\left(58^{\circ} 59^{\prime} 39^{\prime \prime} \mathrm{N}, 17^{\circ} 22^{\prime} 37^{\prime \prime} \mathrm{E}\right)$. It was constructed in 2003 to increase biodiversity and favor nutrient removal. The wetland was constructed on a mineral clay soil by digging out and flooding an old ditch, and the removed top soil was used to create four islands. The size of the wetland is 2.1 ha with a catchment area of 96 ha (34 ha arable land, 56 ha forest, and 6 ha pastures). The catchment is divided into three areas, where the largest sub-catchment (area 1 with 80 ha including 27 ha arable land) drains to the inlet pipe, and the other two to the sides of the wetland

(Fig. 1). Sanitary wastewater from two households is discharged through a sewage pipe from area 3. A monitoring study has shown that the wastewater contained mainly soluble P; approximately $88 \%$ of the total P (TP) in the incoming wastewater (Karlsson, 2005).

\section{Water sampling analyses and load calculations}

Since April 2004, rainfall has been measured and flow proportional water samples have been taken at the inlet and outlet using combined flow meters and water samplers, SIGMA 900 MAX. Sampling volume and frequency was regulated depending on season and expected water flow. 
The sampling volume varied between 15 and $100 \mathrm{ml}$, and the sampler was set to take a sample every $3-25 \mathrm{~m}^{3}$ depending on the flow. This has resulted in an extensive set of in- and outflow nutrient concentrations and water flow data, available for an accurate calculation of long-term retention of $\mathrm{P}$ based on load and outflow measurements. The water quality analyses have been made at the commercial laboratory ALCONTROL AB using Swedish Standard methods (SIS, 2005).

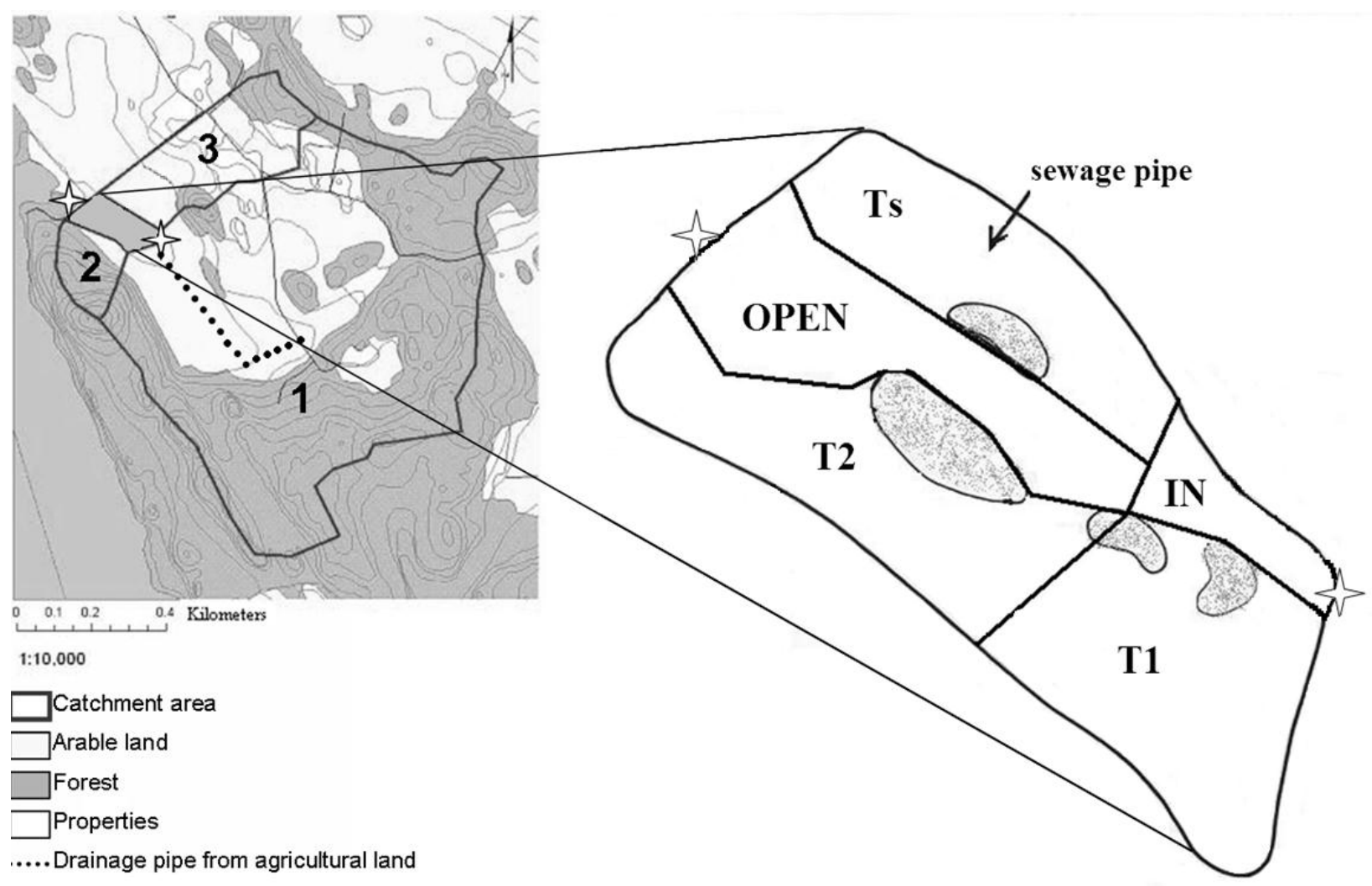

Fig.1. Catchment area for S. Stene wetland. The dark grey area represents the wetland. The sampling stations at the in- and outlet are marked with stars. The sampled inlet receives drainage water from sub-catchment 1, and the wetland receives diffuse P loading from sub-catchments 2 and 3 (Karlsson, 2005). The extension shows the wetland, and the division into five sampling areas; $\mathrm{IN}=$ inlet area, $\mathrm{T} 1=$ shallow section close to the inlet dominated by $T$. latifolia, $\mathrm{T} 2=$ shallow section close to the outlet dominated by T.latifolia, OPEN=deep open water area, Ts=shallow section with T.latifolia receiving drainage water.

During three high-flow periods (3-16 April 2007, 19 Nov-8 Dec 2007, and 29 Feb-13 Mar 2008), grab samples were taken twice daily for $2-3$ weeks, filtered in the field $(0.45 \mu \mathrm{m})$, frozen 
and analyzed for TP (autoclave-mediated digestion, $120^{\circ} \mathrm{C}, 100 \mathrm{kPa}$, with $\mathrm{K}_{2} \mathrm{~S}_{2} \mathrm{O}_{8}$ and $\mathrm{H}_{2} \mathrm{SO}_{4}$ ) for unfiltered and filtered samples, representing TP and dissolved P (DP), respectively.

The wetland in S. Stene has a catchment area with diffuse contributions from sub-catchments 2 and 3 as well as a sewage point source (Fig. 1), apart from the sampled inlet. This means that the load from all three sub-catchments plus the sewage has to be included to make a correct calculation of the $\mathrm{P}$ load and retention. A previous study has investigated the percentage of $\mathrm{P}$ load originating from the smaller sub-catchments (Karlsson, 2005); by extrapolating the load from sub-catchment 1 and assuming that the P loss per area agricultural land and forest was equal in the other two. Results from the investigations showed that sub-catchment 1, i.e. the sampled inlet, contributed $79 \%$ of the $\mathrm{P}$ load, and sub-catchments 2 and 3 contributed $21 \%$. In addition, the P content and flow of the sewage was measured using automatic sampler. The total P load could thus be calculated. The resulting source apportionment indicated that the wastewater contributed $14 \%$ of the annual P load, and that most of the P entering the wetland originated from the arable land (Eriksson et al., 2009).

\section{Sediment sampling and analysis}

The wetland was divided into five areas, representing the inlet (IN), open area near the outlet (OPEN), and the shallow areas dominated by Typha latifolia L. (Ts at the sewage pipe discharge, T1 near the inlet and T2 near the outlet; Fig. 1). In February 2008, six sampling sites were randomly selected in each area. In each site, two sub-samples were collected using a core sampler (diameter $7 \mathrm{~cm}$ ). In samples taken near the inlet, the accumulated sediment (light brown) could be easily distinguished from the dense clay (grey) forming the original bottom of the wetland. The two layers were separated from each other and the upper layer was brought to the laboratory for 
further analyses. Additional samples for density determination were collected using steel cylinders $\left(192 \mathrm{~cm}^{3}\right)$. For each core sample, the thickness of the accumulated sediment was also measured. Additional measurements of sediment thickness were done in the shallow areas (IN, $\mathrm{n}=13 ; \mathrm{T} 1, \mathrm{n}=6 ; \mathrm{T} 2, \mathrm{n}=13 ; \mathrm{Ts}, \mathrm{n}=6$ ) using a metal rod that was gently pushed down into the sediment until it hit the denser underlying clay. The volume of the sediment in T1, T2, Ts and OPEN was calculated by multiplying each surface area with the mean sediment thickness. For the inlet, the P content of each sediment sample was first calculated, and the mean was multiplied with the inlet surface area.

In all samples from the upper sediment layer, plant material was removed, and then they were dried at $35^{\circ} \mathrm{C}$, ground with a mortar and sieved (mesh size $2 \mathrm{~mm}$ ). TP was determined by a method described by Andersen (1976) and recommended by Svendsen et al. (1993). One gram of dried sediment was ignited at $550{ }^{\circ} \mathrm{C}$ for three hours. After ignition, $25 \mathrm{ml} 1 \mathrm{M} \mathrm{HCl}$ was added, and the solution was boiled for 20 minutes. Total inorganic $\mathrm{P}\left(\mathrm{P}_{\mathrm{i}}\right)$ was determined by the same method, only with unignited samples. The difference between $\mathrm{P}_{\mathrm{i}}$ and TP represented the organic $\mathrm{P}$ fraction $\left(\mathrm{P}_{\mathrm{o}}\right)$.

The different $P_{i}$ fractions were separated with a sequential fractionation procedure (for details, see Singh et al. (2005)). $\mathrm{P}_{\mathrm{i}}$ was divided into 1) $\mathrm{NH}_{4} \mathrm{Cl}-\mathrm{P}=$ bioavailable $\mathrm{P}$, 2) $\mathrm{NH}_{4} \mathrm{~F}-\mathrm{P}=$ aluminum-bound $\mathrm{P}, 3) \mathrm{NaOH}-\mathrm{P}=\mathrm{P}$ bound to iron-oxides, and 4) $\mathrm{H}_{2} \mathrm{SO}_{4}-\mathrm{P}=$ calcium-bound $\mathrm{P}$. The $\mathrm{P}$ left in the soil after the fractionation procedure is considered biologically unavailable, hence representing a long-term storage pool in a wetland (Diaz et al., 2006). This insoluble fraction was given by the difference between TP and the sum of the fractions (Rydin, 2000). 
The dissolved $\mathrm{P}$ in all extracts was generally measured as molybdate reactive $\mathrm{P}$ (MRP) using the Swedish standard for P determination (SIS, 1997).

\section{Statistical analysis}

Data (TP) was tested for normal distribution, and then analyzed by analysis of variance (ANOVA), to investigate possible differences between the five areas. Possible relationships between concentrations in grab water samples and corresponding flow data were analyzed by linear regression. All statistical analyses were performed in the software MINITAB 152007.

\section{Results}

During the study period, the wetland received a mean hydraulic load of only $6 \mathrm{~mm} /$ day during the warm low flow season and up to five times higher during the winter, Dec-Feb (Table 1). This represented an average runoff of $143 \mathrm{~mm}$ per year from the catchment. Seasonal mean concentrations of TP at the main inlet varied between 0.07 and $0.18 \mathrm{mg} / \mathrm{l}$ with the highest values in spring, Mar-May.

The results from analyses of grab samples during three high-flow periods showed that PP was the

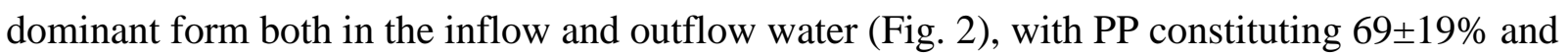
$78 \pm 13 \%$ of $\mathrm{TP}$, respectively. Linear regression analyses showed a positive relationship between PP concentration and water flow both at the inlet and outlet (Fig. 3); $\mathrm{R}^{2}$ (in) $=0.61(\mathrm{p}<0.001)$, $\mathrm{R}^{2}$ (out) $=0.78(\mathrm{p}<0.001)$. However, at the inlet the proportion of PP was low during low-flow and high in high-flow periods, whereas at the outlet there was a constant high proportion of PP in the water (Fig. 2). 


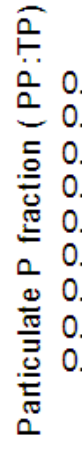
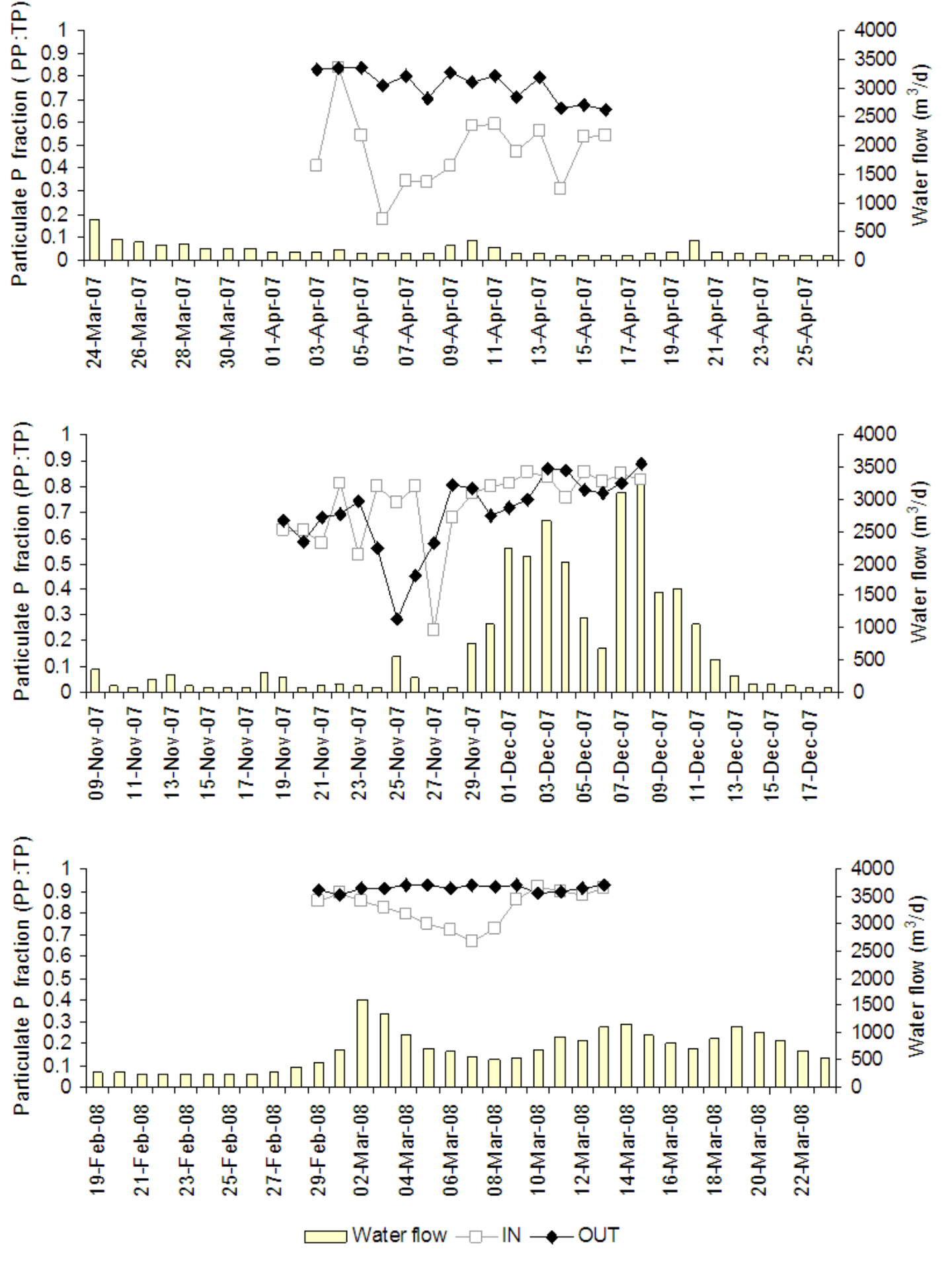

Fig.2. Proportion of particulate phosphorus for in- and outflow water in S. Stene wetland at three sample occasions. Inflow water comes from the main sub-catchment area, and water flow was measured in the inlet. 


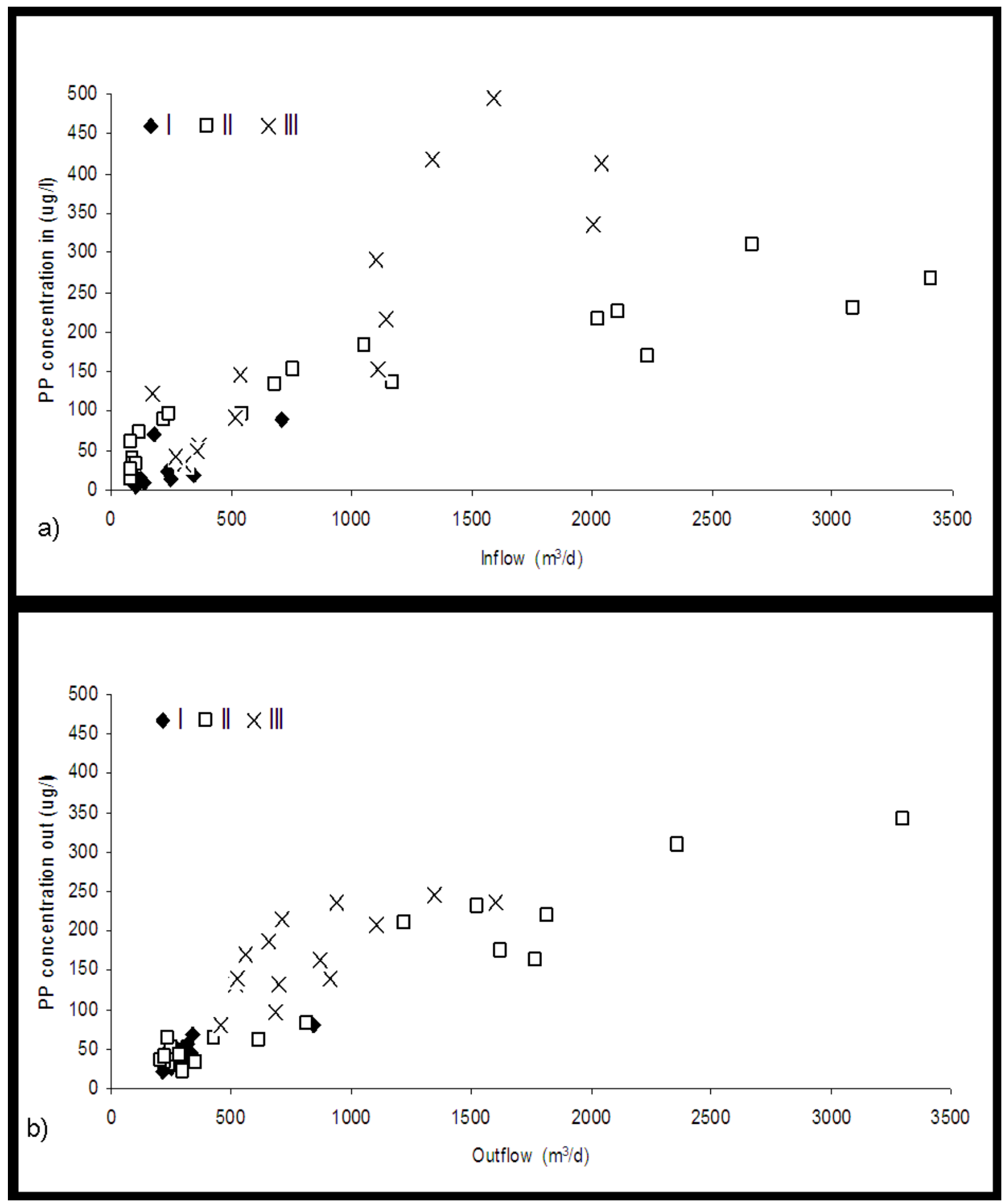

Fig.3. Relationship between water flow and concentration of particulate phosphorus, based on grab sampling at three different occasions (I: 3-16 April 2007, II: 19 Nov-12 Dec 2007, III: 29 Feb-13 Mar 2008) at a) the inlet, and b) the outlet of S. Stene wetland. 
Since the start of measurements in April 2004, P was retained in the wetland, based on inflow and outflow water quality analyses and flow measurements, with a mean retention of $17 \%$, which equaled $2.8 \mathrm{~kg} / \mathrm{ha} / \mathrm{yr}$ (Table 2). There was a large interannual difference with $6.2 \mathrm{~kg} / \mathrm{ha} / \mathrm{yr}$ during the year with highest load. P was released from the wetland during some cold months with high flows (Fig. 4), but not during high flows in other seasons, for example in April-May 2005 and 2006 or Feb-Apr 2007. In the first years, the P release from the wetland corresponded with periods of temperature below zero, and possible ice cover.

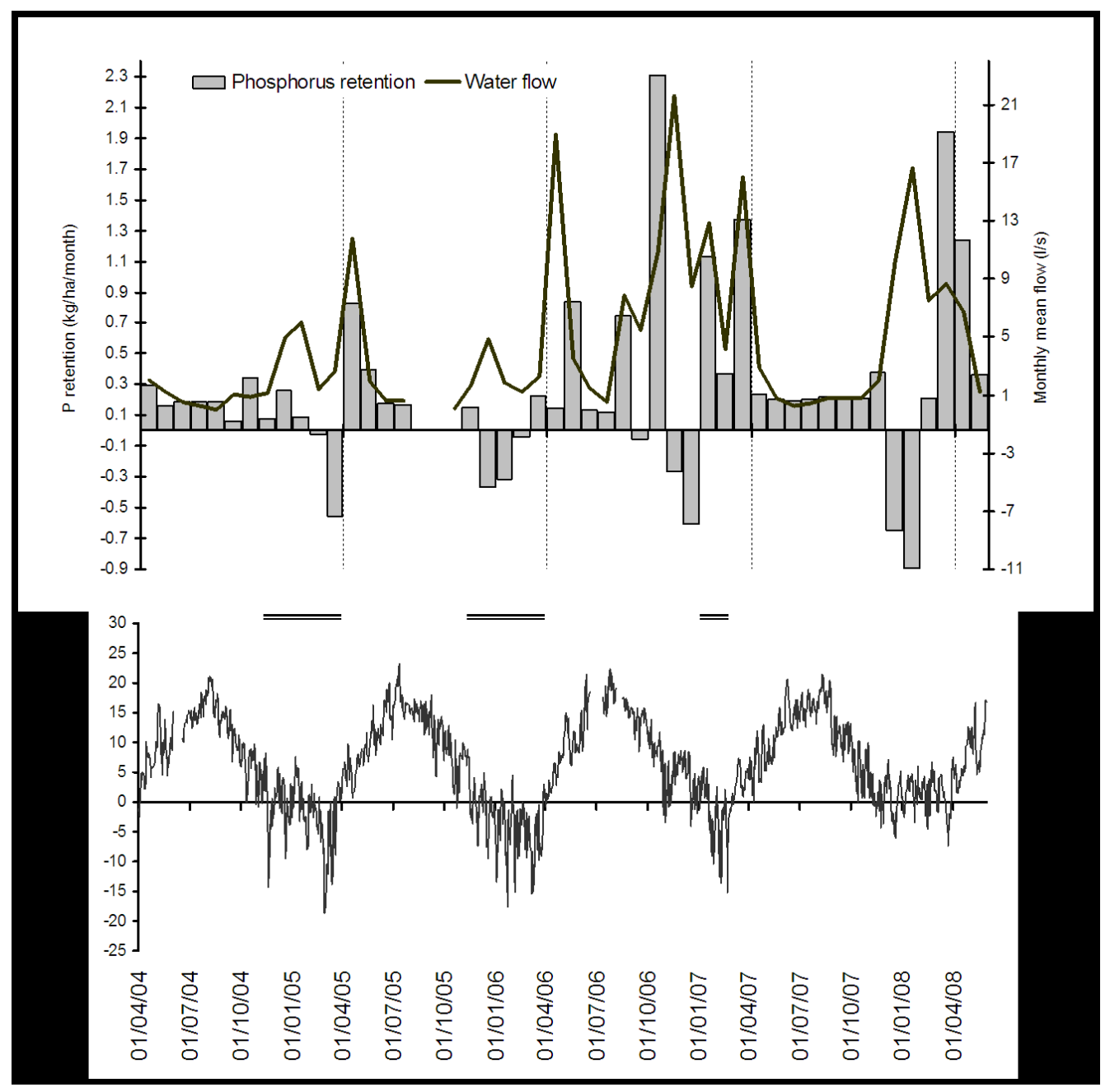

Fig.4. Phosphorus retention, based on inflow and outflow calculations, water flow and daily air temperature for S. Stene wetland. Water flow was measured at the outlet. Negative temperature could indicate ice coverage in the wetland, which is marked by double lines above the temperature diagram. 
Sediment thickness was more than four times higher at the inlet compared to the other parts of the wetland (Table 3), and the sedimentation rate in this area was $22 \mathrm{~kg} / \mathrm{m}^{2} / \mathrm{yr}$ (with a mean dry bulk density of $550 \mathrm{~kg} / \mathrm{m}^{3}$ ). The amount of $\mathrm{P}$ contained in that sediment corresponded to almost $80 \%$ of the $\mathrm{P}$ load (Table 3). The amount of $\mathrm{P}$ in the uppermost, newly formed sediment in the areas dominated by $T$. latifolia was $>3$ times larger than the total P load during four years of wetland operation. In the open area closest to the outlet, half of the samples had no visible accumulated sediment layer.

On average, $22 \%$ of the $\mathrm{P}$ in the accumulated sediment in S. Stene wetland was found in stable forms i.e. bound to calcium-carbonate or the residual fraction not extracted in the sequential fractionation (Table 4). $\mathrm{NH}_{4} \mathrm{Cl}-\mathrm{P}$ represents the bioavailable $\mathrm{P}$ in the sediment, and this fraction was small $(0.2 \%)$. The Fe/Al-P fraction was large (almost $40 \%$ ), though the proportion bound as Fe-P could not be successfully separated with the chosen fractionation scheme.

At the inlet, where almost all the $\mathrm{P}$ from sub-catchment 1 settled, 24\% of the $\mathrm{P}$ was found in stable forms (i.e. Ca-P and residual-P), and $43 \%$ was bound to organic material. Here, the Fe/Al$\mathrm{P}$ fraction was $33 \%$. A comparison of $\mathrm{P}$ fractions in the inlet sediment and two of the T. latifolia dominated areas (T1 and T2), showed a significantly higher amount of calcium-bound $\mathrm{P}$ at the inlet $(\mathrm{p}=0.003)$.

\section{Discussion}

The wetland in S. Stene received a low hydraulic load when comparing with wetlands in other studies, and could therefore be expected to have high relative (\% of load) retention. The analysis of data from 15 wetlands by Braskerud et al. (2005) indicated that the relative TP retention 
increased with an increasing ratio wetland area to catchment area and leveled out at about 1-2\%. However, the variation was high and two out of four wetlands with similar hydraulic and TP loads had a relative removal efficiency of $23 \%$ in comparison with $62-88 \%$ for the other two. During individual years, negative retention was occasionally observed in that data set, as has also sometimes been reported for natural wetlands (Fisher \& Acreman, 2004). In a more recent study of a low-loaded wetland in Switzerland, the retention was $23 \%$ of the $\mathrm{P}$ load, or $11 \mathrm{~kg} / \mathrm{ha} / \mathrm{yr}$ (Reinhardt et al., 2005). As commonly observed for constructed wetlands (Kadlec, 2005), the area-specific TP retention in S. Stene was higher during high-flow years when the load was higher. However, in comparison with the cited studies, both the mean area-specific and relative $\mathrm{P}$ retention in S. Stene wetland was low, $2.8 \mathrm{~kg} / \mathrm{ha} / \mathrm{yr}$ or $17 \%$ of the load (Table 2 ). One possible explanation could be an underestimation of the $\mathrm{P}$ load at the main wetland inlet. As noted by Jarvie et al. (2002) it is hard to obtain representative samples when sampling water with a high proportion of PP. The measured TP loss from the arable land in S. Stene catchment was 0.26 $\mathrm{kg} / \mathrm{ha} / \mathrm{yr}$ (when sewage pipes and background leakage from forest had been accounted for), and a study of a drained clay soil situated in the same geographical area showed a very similar P loss of $0.29 \mathrm{~kg} / \mathrm{ha} / \mathrm{yr}$ (Ulén \& Persson, 1999). PP dominated (63\%) with MRP and other colloidal/dissolved forms amounting to $23 \%$ and $14 \%$, respectively, which agrees well with the measured PP and total dissolved P proportion of 69 and $31 \%$ in the wetland inlet during high flow periods. This suggests that the results from the water sampling program were reasonable estimates of the actual P load to the wetland. As the land use and soil type is the same in the entire catchment, it is likely that the non-measured $\mathrm{P}$ losses from the agricultural fields in subcatchments 2 and 3 (17\% of the area; Fig. 1) were similar to catchment 1 . The P load from the sewage pipe was measured during one month using an automatic sampler (Karlsson, 2005) and a 
mean value used in the load calculations. Hence, the estimated part of the total P load is probably reasonably accurate (Table 2 ).

Another possible explanation for the low retention could be a short-circuiting of the flow from the sewage pipe, as it discharged mainly dissolved $\mathrm{P}$ near the wetland outlet. The $\mathrm{P}$ in sewage contributed about $14 \%$ of the total annual P load, but during low-flow periods it accounted for the major part of the load. During Jun-Aug 2004 (Fig. 4), sewage P input amounted to 78\% of the total TP load, and the corresponding figure for Jun-Aug 2007 was 90\%. However, the total P retention was high during those periods (2004: $0.19 \mathrm{~kg} / \mathrm{ha} / \mathrm{month}$ or $92 \% ; 2007: 0.20 \mathrm{~kg} / \mathrm{ha}^{\prime}$ month or $88 \%$ ) suggesting that sewage short-circuiting was not a main cause for the low annual $\mathrm{P}$ retention.

The depth of accumulated sediment close to the inlet ranged from 10-30 cm (Table 3) with a thicker layer closest to the inlet pipe, showing that the wetland functioned as a sedimentation unit. The $\mathrm{P}$ content of this accumulated sediment amounted to almost $80 \%$ of the $\mathrm{P}$ load, so there was an efficient settling of PP, as has been concluded in several other studies of wetlands constructed for treatment of nutrients from diffuse sources (e.g. Braskerud, et al., 2000; Carleton et al., 2001; Coveney et al., 2002; Braskerud, 2002, 2003). The amount of $\mathrm{P}$ in the accumulated sediment in the inlet (Table 3) was calculated using the mean $\mathrm{P}$ content for the whole area of $1150 \mathrm{~m}^{2}$. Using the minimum and maximum concentrations resulted in a variation of $87-125 \mathrm{~kg}$, indicating that the particle settling in the inlet zone corresponded to a removal of between $64-92 \%$ of the TP entering the wetland. This is considerably more than what was indicated from the inflow and outflow estimates alone. Hence, the interpretation of the results from such studies would benefit from measurements of sediment accumulation. 
The efficiency of the wetland as a trap for inflowing particles is also seen in the data from one of the grab sampling periods, when in the period Feb 29-Mar 132008 a sudden increase in the inlet $\mathrm{PP}$ concentrations occurred as the water flow increased above 1100-1200 $\mathrm{m}^{3} / \mathrm{d}$ (Fig. 3). The lack of a corresponding concentration increase in PP at the outlet also confirmed that a substantial part of the inflowing particles settled in the wetland. The high particle settling in the inlet zone corresponded to an annual sedimentation rate of $22 \mathrm{~kg} / \mathrm{m}^{2} / \mathrm{yr}$, which is lower than the $40-90$ $\mathrm{kg} / \mathrm{m}^{2} / \mathrm{yr}$ observed in small wetlands receiving high loads of particle rich water in Norway (Braskerud et al., 2000). Despite the high hydraulic load in those wetlands, a large proportion of fine particles (silt and clay) settled in the sedimentation basin near the inlet. Settling of particulate matter at the inlet is a retention process that requires continuous management, e.g. by removing accumulated sediment in order to maintain the retention capacity (Søndergaard et al., 2003).

As seen from Figure 4, there were periods of net P release from S. Stene wetland, despite the efficient removal of inflowing PP. All those periods occurred during cold months and were coherent with relatively high flows. Release of TP during high flow periods has often been observed in inflow/outflow studies of constructed wetlands receiving non-point source runoff (e.g. Reinelt \& Horner, 1995; Braskerud, 2002; Hoffmann et al., 2009). Carleton et al. (2001) reviewed data from 49 wetlands receiving storm water runoff and fitted both an areal P removal model (where the wetland volume is not included) and a volumetric model (where the detention time is used instead of the hydraulic load) to the data set. They found that the difference in TP removal between wetlands was better described by the model including differences in mean detention time. The authors suggested that a partial explanation could be that when intermittent high inflow rates occur, settled solids are resuspended and this offsets the influence of a low 
mean hydraulic loading rate. In S. Stene, the proportion of PP was high in the outflow water during all the grab sampling periods (Fig. 2), which shows that PP was the dominant form of $\mathrm{P}$ leaving the wetland during both high and low-flow periods. Since most of the inflowing PP settled close to the inlet, most of the PP leaving the wetland must have originated from within the wetland. As the outflow zone consisted of an open pond dug in clay, internal erosion caused by e.g. high water flow could have contributed to resuspension of fine particles. The thin layer of newly formed sediment in this part of the wetland (in half of the samples, no accumulation at all could be observed) gives some support for this explanation (Table 3). Bioturbation by invertebrates or the large amount of birds feeding and resting in the wetland, as well as growth of algae, could have contributed to a high proportion of PP in the outflow during the warmer months, but those periods with low water flows had little importance for the overall $\mathrm{P}$ retention in the wetland (Fig. 4).

Another source of TP in the outflow could be $\mathrm{P}$ released during decomposition of litter and sediment organic matter. About $70 \%$ of the $\mathrm{P}$ was found in the newly formed sediment of the $T$. latifolia areas; equivalent to more than three times the P load (Table 3). The source of this $\mathrm{P}$ was likely not PP from sub-catchment 1, since a majority of that P settled immediately upon entering the wetland. Sub-catchments 2 and 3 contributed approximately $21 \%$ of the total P load to the wetland, but this input alone can not explain the high amount of $\mathrm{P}$ in the upper sediment layer of the shallow vegetated areas. Emergent macrophytes, such as T. latifolia, are able to supply their nutrient demand from the sediments alone, acting as $\mathrm{P}$ "pumps" transferring $\mathrm{P}$ from the sediment to the aboveground plant tissues (Granéli \& Solander, 1988). Though the topsoil had been removed, it is likely that the mineral soil on which the wetland was constructed contained $\mathrm{P}$ available to plants as it was formerly agricultural land. Gottschall et al. (2007) studied an eight 
years old wetland treating dairy wastewater in eastern Ontario and found that at the end of the growing season the P storage in above- and below-ground biomass of a Typha spp. community was $39-48 \mathrm{~kg} / \mathrm{ha}$. In S. Stene, more than $50 \%$ of the wetland was covered by emergent vegetation, predominantly T. latifolia, representing $>1$ ha. Assuming a similar $\mathrm{P}$ content as in the Canadian study, an amount equivalent of the whole $\mathrm{P}$ load $(16 \mathrm{~kg} / \mathrm{ha} / \mathrm{yr})$ could have been incorporated into the plant community that established during the initial four years. However, it is known that more than $80 \%$ of $\mathrm{P}$ can be released after die back of plants due to litter decomposition (Kadlec, 2005). Puriveth (1980) studied decomposition of T. latifolia litter in a temperate region and showed that most of the $\mathrm{P}$ was rapidly released. After three months, the $\mathrm{P}$ loss amounted to $60 \%$ and $80 \%$ in the above- and below-ground litter, respectively. Although not quantified in the present study, this internal cycling of $\mathrm{P}$ could have affected the net TP retention in the wetland.

The lack of difference in organic-P content between the sediment from the inlet area and the $T$. latifolia dominated areas (Table 4) was not surprising since the wetland was young (4.5 years). The $\mathrm{P}$ fractionation results suggest that up to $80 \%$ of the $\mathrm{P}$ in the upper sediment layer (the organic and iron- and aluminum bound P) was potentially available for cycling and/or release (Table 4), though not directly mobile. The $\mathrm{P}$ fraction associated with iron and aluminum compounds in the areas dominated by $T$. latifolia $(80 \mathrm{~kg})$ alone amounted to more than double the annual load to the wetland (Table 3). This further emphasizes the risk for future P losses in the course of $\mathrm{P}$ diagenetic processes in the wetland sediment. It is possible that during the winter 2005/2006 release of dissolved P bound to Fe (III) oxides contributed to the observed net losses in December and January; however it was not investigated in detail (Fig. 4). Release of soluble P from sediment storage pools, resulting in recently restored wetlands acting as net sources of $\mathrm{P}$ has been observed but commonly when flooding agricultural soils rich in organic matter (reviewed by 
Reddy et al., 1999; Kadlec, 2005; Hoffmann et al., 2009). S. Stene was constructed on a mineral soil, and as much of the topsoil was removed there was little risk for release of mobile P from the soil. However, as more litter and organic sediment accumulate in the vegetated areas, the risk for development of anoxic conditions, with subsequent release of P bound to Fe (III) oxides, increase. Harvesting the aboveground plant biomass could be one way of removing organic matter and decreasing the oxygen demand in the sediments. In addition, considerable amounts of $\mathrm{P}$ would be removed; Hoffmann et al (2009) give values of 4-15 kg P/ha/yr in harvested biomass from wetlands. The timing and frequency of harvest must be properly chosen to sustain a high $\mathrm{P}$ uptake as studies have noted that frequent above-ground harvesting can slow the growth and biomass production of both T. latifolia and T. angustifolia (Sale \& Wetzel, 1983; Jinadasa et al., 2008).

\section{Conclusions}

During the first four years after construction, S. Stene wetland acted as a trap for clay-bound P, but with a low annual P retention of $2.8 \mathrm{~kg}$ P/ha, or $17 \%$ of the load. The dominating retention process was sedimentation, and a large proportion of inflowing particles settled immediately upon entering the wetland $-78 \%$ of the $\mathrm{P}$ load was found in the sediment near the inlet. The large discrepancy between the estimates shows the need to add measurements of sediment accumulation to inflow-outflow studies for an improved understanding of $\mathrm{P}$ retention in constructed wetlands.

The rapid sediment accumulation at the inlet $\left(22 \mathrm{~kg} / \mathrm{m}^{2} / \mathrm{yr}\right)$ will require repeated removal of the sediment to sustain an efficient PP retention in this section. The stores of $\mathrm{P}$ in the upper sediment layer were substantially larger than the annual load of $\mathrm{P}$ to this wetland and there is a risk for 
future release of $\mathrm{P}$ from those pools. Harvesting the emergent vegetation would be one way to reduce the risk for redox-induced release of soluble $\mathrm{P}$ and also to remove $\mathrm{P}$ from the wetland.

Despite the high removal of inflowing PP, there was an outflow of predominantly PP from the wetland. Net release of $\mathrm{P}$ occurred each year during 1-2 cold months with high water flow. It remains open to which extent the release of $\mathrm{P}$ bound to Fe (III) oxides or other processes like sediment erosion or litter decomposition can explain this phenomenon.

\section{Acknowledgements}

The authors would like to thank Per-Richard Bernström at S. Stene farm, without whom there would not be a wetland in the first place, for managing the water sampling. Two anonymous reviewers and the guest editor are also acknowledged for extensive and helpful comments. The project received financial support from the Stockholm County Council, the Swedish EPA and Board of Agriculture, the Foundation for Strategic Environmental Research (through the research program VASTRA), and the Rural Development Program.

\section{References}

Andersen, J. M., 1976. An ignition method for determination of total phosphorus in lake sediments. Water Research 10: 329-331.

Braskerud, B. C., 2002. Factors affecting phosphorus retention in small constructed wetlands treating agricultural non-point source pollution. Ecological Engineering 19: 41-61.

Braskerud, B. C., 2003. Clay particle retention in small constructed wetlands. Water Research 37:3793-3802. 
Braskerud, B. C., H. Lundekvam \& T. Krogstad, 2000. The impact of hydraulic load and aggregation on sedimentation of soil particles in small constructed wetlands. Journal of Environmental Quality 29: 2013-2020.

Braskerud, B. C., K. S. Tonderski, B. Wedding, R. Bakke, A. G. Blankenberg, B. Ulén \& J. Koskiaho, 2005. Can constructed wetlands reduce the diffuse phosphorus loads to eutrophic water in cold temperate regions? Journal of Environmental Quality 34: 2145-2155.

Bruland, G. L. \& C. J. Richardson, 2006. An assessment of the phosphorus retention capacity of wetlands in the Painter Creek watershed, Minnesota, USA. Water, Air, and Soil Pollution 171: $169-184$.

Carleton, J. N., T. J. Grizzard, A. N. Godrej \& H. E. Post, 2001. Factors affecting the performance of storm water treatment wetlands. Water Research 35: 1552-1562.

Coveney, M. F., D. L. Stites, E. F. Lowe, L. E. Battoe \& R. Conrow, 2002. Nutrient removal from eutrophic lake water by wetland filtration. Ecological Engineering 19: 141-159.

Diaz, O. A., S. H. Daroub, J. D. Stuck, M. W. Clark, T. A. Lang \& K. R. Reddy, 2006. Sediment inventory and phosphorus fractions for water conservation area canals in the Everglades. Soil Science Society of America Journal 70: 863-871.

Eriksson, S., J. L. Andersson, K. S. Tonderski \& K. Johannesson, 2009. Södra Stene wetland and other constructed wetlands in Mälardalen - a follow-up of the Environmental Objectives (Våtmarken i Södra Stene och andra våtmarker i Mälardalen - uppföljning av miljömålen). Stockholm, Sweden: Regionplane- och trafikkontoret, RTK. In Swedish. 
Fisher, J. \& M. C. Acreman, 2004. Wetland nutrient removal: A review of the evidence. Hydrology and Earth System Sciences 8: 673-685.

Gottschall, N., C. Boutin, A. Crolla, C. Kinsley \& P. Champagne, 2007. The role of plants in the removal of nutrients at a constructed wetland treating agricultural (dairy) wastewater, Ontario, Canada. Ecological Engineering 29: 154-163.

Granéli, W. \& D. Solander, 1988. Influence of aquatic macrophytes on phosphorus cycling in lakes. Hydrobiologia 170: 245-266.

HELCOM Baltic Sea action plan. HELCOM Ministerial Meeting. Krakow, Poland, 2007.

Hoffmann, C. C., C. Kjaergaard, J. Uusi-Kämppä, H. C. Hansen \& B. Kronvang, 2009. Phosphorus retention in riparian buffers: review of their efficiency. Journal of Environmental Quality 38: 1942-1955.

Jarvie, H. P., P. J. A. Withers \& C. Neal, 2002. Review of robust measurement of phosphorus in river water: Sampling, storage, fractionation and sensitivity. Hydrology and Earth System Sciences 6: 113-132.

Jinadasa, K. B. S. N., N. Tanaka, S. Sasikala, D. R. I. B. Werellagama, M. I. M. Mowjood \& W. J. NG, 2008. Impact of harvesting on constructed wetlands performance-a comparison between Scirpus grossus and Typha angustifolia. Journal of Environmental Science and Health Part A 43: 671-678

Kadlec, R. H., 2005. Phosphorus removal in emergent free surface wetlands. Journal of Environmental Science and Health 40:1293-1306. 
Karlsson, M., 2005. Nutrient load to a constructed wetland from agriculture, forest and sewage (Näringsbelastning på en anlagd våtmark från åker, skog och enskilda avlopp). Swedish University of Agricultural Sciences, Division of Water Quality, Seminars and project series No. 50. In Swedish.

Koskiaho, J., P. Ekholm, M. Räty, J. Riihimäki \& M. Puustinen, 2003. Retaining agricultural nutrients in constructed wetlands - experiences under boreal conditions. Ecological Engineering 20: 89-103.

Maynard, J. J., A. T. O'Geen \& R. A. Dahlgren, 2009. Bioavailability and fate of phosphorus in constructed wetlands receiving agricultural runoff in the San Joaquin Valley, California. Journal of Environmental Quality 38: 360-372.

Pacini, N. \& R. Gächter, 1999. Speciation of riverine particulate phosphorus during rain events. Biogeochemistry 47: 87-109.

Persson, G., 2001. Phosphorus in tributaries to Lake Mälaren, Sweden: Analytical fractions, anthropogenic contribution and bioavailability. Ambio 30: 486-495.

Puriveth, P., 1980. Decomposition of emergent macrophytes in a Wisconsin marsh. Hydrobiologia 72: 231-242.

Reddy, K. R., R. H. Kadlec, E. Flaig \& P. M. Gale, 1999. Phosphorus retention in streams and wetlands: A review. Critical Reviews in Environmental Science and Technology 29: $83-146$. 
Reinelt, R. E. \& R. R. Horner, 1995. Pollutant removal from storm water runoff by palustrine wetlands based on comprehensive budgets. Ecological Engineering 4: 77-97.

Reinhardt, M., R. Gächter, B. Wehrli \& B. Müller, 2005. Phosphorus retention in small constructed wetlands treating agricultural drainage water. Journal of Environmental Quality 34: $1251-1259$.

Richardson, C. J., 1999. The role of wetlands in storage, release, and cycling of phosphorus on the landscape: a 25 years retrospective. In: Reddy, K. R., G.A. O’Connor \& C.L. Schleske (eds), Phosphorus biogeochemistry of subtropical ecosystems. CRC Press LLC: 47-65.

Richardson, C. J. \& S. S. Qian, 1999. Long-term phosphorus assimilative capacity in freshwater wetlands: A new paradigm for sustaining ecosystem structure and function. Environmental Science and Technology 33: 1545-1551.

Rydin, E., 2000. Potentially mobile phosphorus in Lake Erken sediment. Water Research 34: 2037-2042.

Sale, P. J. M. \& R. G. Wetzel, 1983. Growth and metabolism of Typha species in relation to cutting treatments. Aquatic Botany 15: 321-334.

Singh, B. R., T. Krogstad, Y. S. Shivay, B. G. Shivakumar \& M. Bakkegard, 2005. Phosphorus fractionation and sorption in P-enriched soils of Norway. Nutrient Cycling in Agroecosystems 73: 245-256.

SIS, 1997. Water quality - Determination of phosphorus - Ammonium molybdate spectrometric method (SS-EN 1189). Swedish Standards Institute, Stockholm. 
SIS, 2005. Water quality - Determination of phosphorus - Ammonium molybdate spectrometric method (SS-EN 6878). Swedish Standards Institute, Stockholm.

Svendsen, L. M., A. Rebsdorf \& P. Nornberg, 1993. Comparison of methods for analysis of organic and inorganic phosphorus in river sediment. Water Research 27: 77-83.

Søndergaard, M., J. P. Jensen \& E. Jeppesen, 2003. Role of sediment and internal loading of phosphorus in shallow lakes. Hydrobiologia 506-509: 135-145.

Tonderski, K. S., B. Arheimer \& C. B. Pers, 2005. Modeling the impact of potential wetlands on phosphorus retention in a Swedish catchment. Ambio 34: 544-551.

Ulén, B., 2004. Size and settling velocities of phosphorus-containing particles in water from agricultural drains. Water, Air and Soil Pollution 157: 331-343.

Ulén, B., 2006. Sweden. In Boardman, J. \& J. Poesen (eds), Soil erosion in Europe. John Wiley \& Sons, Ltd: 17-25.

Ulén, B. \& K. Persson, 1999. Field-scale phosphorus losses from a drained clay soil in Sweden. Hydrological Processes 13: 2801-2812.

Ulén, B., M. Bechmann, J. Fölster, H. P. Jarvie \& H. Tunney, 2007. Agriculture as a phosphorus source for eutrophication in the north-west European countries, Norway, Sweden, United Kingdom and Ireland: A review. Soil use and Management 23: 5-15.

Uusitalo, R., M. Yli-Halla \& E. Turtola, 2000. Suspended soil as a source of potentially bioavailable phosphorus in surface runoff waters from clay soils. Water Research 34: 2477-2482. 
Uusitalo, R., E. Turtola, M. Puustinen, M. Paasonen-Kivekäs \& J. Uusi-Kämppä, 2003.

Contribution of particulate phosphorus to runoff phosphorus bioavailability. Journal of Environmental Quality 32: 2007-2016.

Øygarden, L., H. Lundekvam, A. H. Arnoldussen \& T. Børresen, 2006. Norway. In Boardman, J. \& J. Poesen (eds), Soil erosion in Europe. John Wiley \& Sons, Ltd: 3-15. 


\section{Tables}

Table 1. Hydraulic load and concentrations of total phosphorus, TP (mean \pm SE) at the main inflow of S. Stene wetland. The values are seasonal means for four years (2004-2008).

\begin{tabular}{lll} 
Time period & Hydraulic load $(\mathrm{mm} / \mathrm{d})$ & TP in $(\mathrm{mg} / \mathrm{l})$ \\
\hline Dec-Feb & $28 \pm 16$ & $0.16 \pm 0.05$ \\
Mar-May & $26 \pm 5$ & $0.18 \pm 0.09$ \\
Jun-Aug & $6 \pm 6$ & $0.07 \pm 0.004$ \\
Sep-Nov & $20 \pm 27$ & $0.11 \pm 0.03$
\end{tabular}

Table 2. Phosphorus load and retention in S. Stene wetland during four years, based on flow proportional water samples ( $\mathrm{n}=40$ per year) and continuous flow measurements at the inlet and outlet. A sampling year was between $1^{\text {st }}$ April and $31^{\text {st }}$ March. The total relative retention represents the sum for the four years. Wetland area $=2.1$ ha.

\begin{tabular}{|c|c|c|c|c|}
\hline Year & $\begin{array}{c}\text { Hydraulic load } \\
\text { (m/yr) }\end{array}$ & $\begin{array}{c}P_{\text {in }} \\
(\mathrm{kg} / \mathrm{ha})\end{array}$ & $\begin{array}{c}P_{\text {out }} \\
(\mathrm{kg} / \mathrm{ha})\end{array}$ & $\begin{array}{c}\text { Retention } \\
\text { (kg/ha) }\end{array}$ \\
\hline
\end{tabular}

\begin{tabular}{|c|c|c|c|c|c|c|}
\hline & & Catchment 1 & $\begin{array}{c}\text { Catchment 2+3 } \\
\text { and sewage }\end{array}$ & & & \\
\hline $2004 / 2005$ & 2.8 & 3.1 & 3.0 & 4.9 & 1.2 & 20 \\
\hline $2005 / 2006$ & 3.4 & 6.1 & 3.8 & 8.2 & 1.7 & 17 \\
\hline $2006 / 2007$ & 14 & 23 & 8.4 & 26 & 6.2 & 19 \\
\hline $2007 / 2008$ & 6.5 & 12 & 5.3 & 15 & 2.1 & 12 \\
\hline Total & 27 & 44 & 21 & 54 & 11 & 17 \\
\hline
\end{tabular}


Table 3. P amount (based on dry matter) in the sediments in the five different areas in S. Stene wetland compared to total $\mathrm{P}$ load and $\mathrm{P}$ retention based on mass balance estimates. Also surface area, sediment thickness (mean $\pm \mathrm{SE})$ and phosphorus content (mean $\pm \mathrm{SE})$ in the five different areas in S. Stene wetland.

$$
\begin{array}{ccc}
\text { P amount }(\mathrm{kg}) \quad \text { Area }\left(\mathrm{m}^{2}\right) & \text { Mean sediment } & \text { TP }(\mathrm{mg} / \mathrm{kg}) \\
& \text { thickness }(\mathrm{cm})
\end{array}
$$

\begin{tabular}{|c|c|c|c|c|}
\hline Subareas & & & & \\
\hline IN & 106 & 1150 & $16 \pm 15$ & $1056 \pm 135$ \\
\hline OPEN & 50 & 4350 & $1 \pm 2$ & $957 \pm 83$ \\
\hline T1 & 142 & 4225 & $5 \pm 2$ & $953 \pm 113$ \\
\hline $\mathrm{T} 2$ & 133 & 4250 & $4 \pm 1$ & $844 \pm 184$ \\
\hline Ts & 115 & 3875 & $4 \pm 1$ & $906 \pm 174$ \\
\hline Total & 546 & & & \\
\hline Load & 136 & & & \\
\hline Retention & 23 & & & \\
\hline
\end{tabular}


Table 4. Amount (based on dry matter) and proportion of organic phosphorus $(\mathrm{P})$ and sequentially extracted inorganic P fractions according to Singh et al. (2005) for the accumulated sediment for the entire S. Stene wetland, inlet area and the mean of two shallow vegetated areas (Typha 1 and Typha 2).

\begin{tabular}{|c|c|c|c|c|c|c|c|}
\hline \multirow[t]{2}{*}{ Extractant } & \multirow[t]{2}{*}{$P$ form } & \multicolumn{2}{|c|}{ Whole wetland sediment } & \multicolumn{2}{|c|}{ Inlet sediment } & \multicolumn{2}{|c|}{ Typha $1 \& 2$ sediment } \\
\hline & & $(\mathrm{mg} / \mathrm{kg})$ & $(\%$ of TP) & $(\mathrm{mg} / \mathrm{kg})$ & $(\%$ of $\mathrm{TP})$ & $(\mathrm{mg} / \mathrm{kg})$ & $(\%$ of TP) \\
\hline & Organic & 365 & 38 & 455 & 43 & 362 & 40 \\
\hline & Inorganic: & & & & & & \\
\hline $\mathrm{NH}_{4} \mathrm{Cl}$ & - bioavailable & 2 & 0.2 & 2 & 0.2 & 2 & 0.2 \\
\hline & $\mathrm{P}$ & & & & & & \\
\hline $\mathrm{NH}_{4} \mathrm{~F}+$ & $-\mathrm{Al}-\mathrm{P}+$ & 377 & 39 & 349 & 33 & 385 & 42 \\
\hline $\mathrm{NaOH}$ & $\mathrm{Fe}-\mathrm{P}$ & & & & & & \\
\hline $\mathrm{H}_{2} \mathrm{SO}_{4}$ & $-\mathrm{Ca}-\mathrm{P}$ & 126 & 13 & 151 & 14 & 95 & 10 \\
\hline & - Residual P & 91 & 9 & 107 & 10 & 72 & 8 \\
\hline
\end{tabular}

